\title{
Rhizobium pseudoryzae sp. nov., isolated from the rhizosphere of rice
}

Correspondence

Ruibo Jiang xxzhang@caas.ac.cn

\author{
Xiaoxia Zhang, ${ }^{1}$ Lei Sun, ${ }^{2}$ Xiaotong Ma, ${ }^{1}$ Xin Hua Sui ${ }^{3}$ and Ruibo Jiang ${ }^{1}$
}
${ }^{1}$ Agricultural Cultural Collection of China, Institute of Agricultural Resources and Regional Planning, Chinese Academy of Agricultural Sciences, Beijing 100081, PR China
${ }^{2}$ College of Life Sciences, Hebei University, Key Laboratory of Microbial Diversity Research and Application of Hebei Province, Baoding 071002, PR China

${ }^{3}$ Key Laboratory of Agro-Microbial Resource and Application, Ministry of Agriculture/College of Biological Sciences, China Agricultural University, Beijing 100094, PR China

\begin{abstract}
A Gram-stain-negative, aerobic, rod-shaped bacterium, designated strain $\mathrm{J} 3-\mathrm{A} 127^{\top}$, was isolated from the roots of fresh rice plants (Oryza sativa). Cells were non-motile and no flagellum was detected. Comparison of $16 \mathrm{~S}$ rRNA gene sequences indicated that the strain was phylogenetically related to species of the genus Rhizobium, with closest similarity to Rhizobium oryzae Alt $505^{\top}(96.4 \%)$. The low levels of $16 \mathrm{~S}$ rRNA gene sequence similarity $(<90 \%)$ found between the $g y r B$, atp $D, \operatorname{rec} A$ and $g / n / l$ gene sequences of strain $\mathrm{J} 3-\mathrm{A} 127^{\top}$ and the type strains of recognized species of the genus Rhizobium also indicated that it represented a separate species. The temperature range for growth was $10-40{ }^{\circ} \mathrm{C}$ (optimum around $28{ }^{\circ} \mathrm{C}$ ) and the $\mathrm{pH}$ range was 6.0-11.0 (optimum pH 7.0-8.0). Strain J3- $\mathrm{A} 127^{\top}$ tolerated $\mathrm{NaCl}$ concentrations up to $5.0 \%$ $(\mathrm{w} / \mathrm{v})$. The strain was catalase- and oxidase-positive. The main cellular fatty acids were summed feature $8\left(\mathrm{C}_{18: 1} \omega 7 \mathrm{c}\right.$ and/or $\left.\mathrm{C}_{18: 1} \omega 6 ; 46.7 \%\right)$. The DNA G+C content of strain J3-A127 ${ }^{\top}$ was $59.5 \mathrm{~mol} \%$. Strain $\mathrm{J} 3-\mathrm{A} 127^{\top}$ did not form any nodules on four different legumes and the nodD and nifH genes were not detected by PCR. According to physiological and biochemical characteristics and genotypic data, strain $\mathrm{J} 3-\mathrm{A} 127^{\top}$ is considered to represent a novel species of the genus Rhizobium, for which the name Rhizobium pseudoryzae sp. nov. is proposed. The type strain is $\mathrm{J} 3-\mathrm{A} 127^{\top}\left(=\right.$ ACCC $10380^{\top}=$ KCTC $\left.23294^{\top}\right)$.
\end{abstract}

The taxonomy of rhizobia is in a state of flux. Since the first description of the genus Rhizobium to accommodate root and/or stem-nodule bacteria by Frank (1889), there have been a number of revisions to its description and the addition of many novel species. At the time of writing, the genus Rhizobium comprises 43 recognized species (Euzéby, 1997; http://www.bacterio.cict.fr/). Species of the genus Rhizobium have traditionally been considered as legume endosymbionts and have generally been isolated from nodules on leguminous plants. More recently, novel species of this genus have also been found in different environments, such as Rhizobium selenitireducens and Rhizobium daejeonense isolated from bioreactors (Quan et al., 2005; Hunter et al., 2007), Rhizobium cellulosilyticum from sawdust of Populus alba (García-Fraile et al., 2007), Rhizobium oryzae from wild rice (Peng et al., 2008) and

The GenBank/EMBL/DDBJ accession number for the $16 \mathrm{~S}$ rRNA gene sequence of strain $\mathrm{J} 3-\mathrm{A} 127^{\top}$ is DQ454123; accession numbers for the $\operatorname{atp} D$, recA, gyrB and $g / n / l$ gene sequences of strain J3-A $127^{\top}$ are EU732562, EU732539, HM132107 and HM132108, respectively.

A supplementary figure and a supplementary table are available with the online version of this paper. strains of Rhizobium alamii from the rhizosphere of sunflowers (Berge et al., 2009). A novel bacterial strain, $\mathrm{J} 3-\mathrm{A} 127^{\mathrm{T}}$, isolated during the course of studies of the bacterial diversity in rice (Oryza sativa) roots, was studied using a polyphasic taxonomic approach. It is proposed that this strain represents a novel species of the genus Rhizobium.

Strain $\mathrm{J} 3-\mathrm{A} 127^{\mathrm{T}}$ was isolated from tillering-stage rice roots from the Agricultural Experimental Demonstration Base at the village of Sangyuan, Luannan County, Hebei Province, China. Methods for the isolation and purification of nitrogen-fixing bacteria on YMA medium (Vincent, 1970) were as described previously (Zhang et al., 2008). Cellular morphology was observed by transmission electron microscopy of bacterial cells grown for $18 \mathrm{~h}$ on YMA (see Supplementary Fig. S1 in IJSEM Online). Utilization of various carbon sources was investigated on GN2 microplates (Biolog) as described by the manufacturer. Growth at $0,4,10,25,30,37,40,45$ and $50{ }^{\circ} \mathrm{C}$ was tested on YMA agar. $\mathrm{NaCl}$ and $\mathrm{pH}$ tolerance were tested by using YMA broth adjusted to $\mathrm{pH} 4.0,5.0,6.0,7.0,8.0,9.0,10.0,11.0$ and 12.0 , and $1,3,4,5,7$ and $10 \%(\mathrm{w} / \mathrm{v}) \mathrm{NaCl}$ (Gao et al., 
1994). Gram-staining and other phenotypic characteristics were determined according to the methods described by Dong \& Cai (2001) and Gao et al. (1994). Discriminative features between the novel isolate and its closest relatives are detailed in Table 1 and in the species description below. Strain $\mathrm{J} 3-\mathrm{A} 127^{\mathrm{T}}$ could be distinguished on the basis of these characteristics from representatives of its closest phylogenetic relatives, namely Rhizobium oryzae Alt $505^{\mathrm{T}}$, Rhizobium sullae $\mathrm{IS}_{123^{\mathrm{T}}}$, Rhizobium mesosinicum CCBAU $25010^{\mathrm{T}}$ and Rhizobium yanglingense CCBAU $71623^{\mathrm{T}}$. In contrast to these type strains, strain J3-A127 ${ }^{\mathrm{T}}$ did not show a flagellum and was able to grow in the presence of $3 \%$ $\mathrm{NaCl}$. Strain $\mathrm{J} 3-\mathrm{A} 127^{\mathrm{T}}$ differed from $R$. oryzae Alt $505^{\mathrm{T}}$ in metabolism of glycogen, Tween 40, Tween 80, adonitol,

Table 1. Differential characteristics between strain J3A-127 and the type strains of closely related species of the genus Rhizobium

Strains: 1, J3A- $127^{\mathrm{T}} ; 2$, R. oryzae Alt $505^{\mathrm{T}}$ (Peng et al., 2008); 3, R. sullae $\mathrm{IS}_{123^{\mathrm{T}}}$ (Squartini et al., 2002); 4, R. mesosinicum CCBAU $25010^{\mathrm{T}}$ (Lin et al., 2009); 5, R. yanglingense CCBAU $71623^{\mathrm{T}}$ (Tan et al., 2001). Data for the reference species are from the present study except for the presence of flagellum and DNA G $+\mathrm{C}$ content, which are from the original sources. + , Positive; - , negative; w, weakly positive.

\begin{tabular}{|c|c|c|c|c|c|}
\hline Characteristic & 1 & 2 & 3 & 4 & 5 \\
\hline Flagellum & - & + & + & + & + \\
\hline DNA G $+\mathrm{C}$ content $(\mathrm{mol} \%)$ & 59.5 & $64.1-64.4$ & 61.6 & 68.1 & $59-63$ \\
\hline \multicolumn{6}{|c|}{ Growth at/with: } \\
\hline pH 5 & - & + & - & + & + \\
\hline $\mathrm{pH} 10$ & + & - & + & + & - \\
\hline $\mathrm{pH} 11$ & + & - & + & - & - \\
\hline $40{ }^{\circ} \mathrm{C}$ & + & + & - & + & - \\
\hline $3 \% \mathrm{NaCl}$ & + & - & - & - & - \\
\hline $\begin{array}{l}\text { Growth in Luria-Bertani } \\
\text { medium }\end{array}$ & + & + & + & + & - \\
\hline \multicolumn{6}{|l|}{ Utilization as carbon source } \\
\hline Glycogen & - & + & - & $\mathrm{w}$ & - \\
\hline Tween 40 & - & + & - & - & - \\
\hline Tween 80 & - & + & - & - & - \\
\hline Adonitol & - & - & + & + & + \\
\hline i-Erythritol & - & - & + & - & + \\
\hline myo-Inositol & + & - & + & + & - \\
\hline$\alpha$-Lactose & + & - & + & + & + \\
\hline Raffinose & - & + & + & $\mathrm{W}$ & - \\
\hline L-Rhamnose & + & - & + & + & + \\
\hline D-Galacturonic acid & + & - & - & $\mathrm{W}$ & - \\
\hline Propionic acid & + & + & - & - & - \\
\hline Quinic acid & + & - & $\mathrm{w}$ & + & - \\
\hline D-Saccharic acid & + & - & - & + & - \\
\hline D-Alanine & + & + & + & - & - \\
\hline L-Leucine & - & + & - & - & - \\
\hline L-Phenylalanine & - & + & - & - & - \\
\hline Glucose 1-phosphate & + & - & - & - & - \\
\hline Glucose 6-phosphate & + & - & - & - & - \\
\hline
\end{tabular}

i-erythritol, $m y o$-inositol, $\alpha$-D-lactose, D-raffinose, Lrhamnose, D-galacturonic acid, quinic acid, D-saccharic acid, L-leucine, L-phenylalanine, glucose 1-phosphate and glucose 6-phosphate and growth at $\mathrm{pH} 11$. It differed from R. sullae IS $123^{\mathrm{T}}$ in metabolism of adonitol, i-erythritol, Draffinose, D-galacturonic acid, propionic acid, D-saccharic acid, glucose 1-phosphate and glucose 6-phosphate and growth at $40{ }^{\circ} \mathrm{C}$. It differed from $R$. mesosinicum CCBAU $25010^{\mathrm{T}}$ in the metabolism of adonitol, i-erythritol, propionic acid, D-alanine, glucose 1-phosphate and glucose 6-phosphate and growth at $\mathrm{pH} 11$ and with $3 \% \mathrm{NaCl}$. It differed from $R$. yanglingense CCBAU $71623^{\mathrm{T}}$ in the metabolism of adonitol, i-erythritol, myo-inositol, Dgalacturonic acid, propionic acid, quinic acid, D-saccharic acid, D-alanine, glucose 1-phosphate and glucose 6phosphate and growth at $\mathrm{pH} 11$ and with $3 \% \mathrm{NaCl}$ (Table 1). The results of a comparison of carbon source utilization with other related species of the genus Rhizobium are shown in Supplementary Table S1.

Fatty acid profiling is a useful tool for the identification of members of the genus Rhizobium and related genera (Tighe et al., 2000). In this study, strain $\mathrm{J} 3-\mathrm{A} 127^{\mathrm{T}}$ and the four reference strains were grown on YMA medium for 2 days at $30{ }^{\circ} \mathrm{C}$. Fatty acid methyl esters were prepared and separated according to method described by Sasser (1990) and were identified with the MIDI Sherlock Microbial Identification System. Strain J3-A127 $7^{\mathrm{T}}$ had a cellular fatty acid profile that was similar to those of other reference strains of the genus Rhizobium (Table 2). The major fatty acids of strain $\mathrm{J} 3-\mathrm{A} 127^{\mathrm{T}}$ were $\mathrm{C}_{18: 1} \omega 7 c$ and/or $\mathrm{C}_{18: 1} \omega 6 c$, which are typical components of root-nodule bacteria (Tighe et al., 2000).

Sequencing of the 16S rRNA gene was performed as described previously (Zhang et al., 2008). Identification of phylogenetic neighbours and calculation of pairwise $16 \mathrm{~S}$ rRNA gene sequence similarity values were achieved by using the EzTaxon server (Chun et al., 2007; http://147.47.212. $35: 8080 /)$. Sequence data were analysed by using the software package MEGA version 4.0 (Tamura et al., 2007), after multiple alignments of the data with CLUSTAL_X 1.83 (Thompson et al., 1997). Distance matrix methods (distance options according to the Kimura two-parameter model), including clustering by the neighbour-joining (Fig. 1) and minimum-evolution methods (data not shown), were used. In each case, bootstrap values were calculated based on 1000 replications. The $16 \mathrm{~S}$ rRNA gene sequence of strain $\mathrm{J} 3-\mathrm{A} 127^{\mathrm{T}}$ was a continuous stretch of $1443 \mathrm{bp}$. Similarity values were calculated by using the same software. Phylogenetic analysis based on 16S rRNA gene sequences revealed that strain $\mathrm{J} 3-\mathrm{A} 127^{\mathrm{T}}$ showed the greatest degree of similarity to $R$. oryzae Alt $505^{\mathrm{T}}(96.4 \%)$, with bootstrap confidence values of $93 \%$ (neighbour-joining method; Fig. 1) and of 95 and $97 \%$ for the minimum-evolution and maximum-parsimony methods, respectively (data not shown). Strain J3-A127 $7^{\mathrm{T}}$ shared lower levels of $16 \mathrm{~S}$ rRNA gene sequence similarity $(<95.6 \%)$ with the type strains of all other recognized species of the genus Rhizobium. 
Table 2. Cellular fatty acids of strain $\mathrm{J} 3 \mathrm{~A}-127^{\top}$ and the type strains of related Rhizobium species

Strains: $1, \mathrm{~J} 3 \mathrm{~A}-127^{\mathrm{T}} ; 2$, R. oryzae Alt $505^{\mathrm{T}} ; 3$, R. sullae $\mathrm{IS} 123^{\mathrm{T}} ; 4, R$. mesosinicum CCBAU $25010^{\mathrm{T}} ; 5$, R. yanglingense CCBAU $71623^{\mathrm{T}}$. All data were obtained in this study. A dash indicates $<2 \%$ or not detected.

\begin{tabular}{|lccccc|}
\hline Fatty acid & $\mathbf{1}$ & $\mathbf{2}$ & $\mathbf{3}$ & $\mathbf{4}$ & $\mathbf{5}$ \\
\hline Summed feature $2^{*}$ & 10.40 & 6.30 & 4.83 & 4.51 & 6.49 \\
Summed feature $3^{*}$ & 3.08 & - & - & - & - \\
$\mathrm{C}_{16: 0}$ & 12.73 & 28.71 & 9.98 & 9.94 & 4.82 \\
$\mathrm{C}_{17: 0}$ cyclo & - & 3.78 & - & - & - \\
$\mathrm{C}_{16: 0}$ 3-OH & 3.64 & - & - & - & 2.72 \\
Summed feature $8^{*}$ & 46.71 & 32.89 & 63.81 & 44.62 & 74.47 \\
$\mathrm{C}_{18: 0}$ & - & 2.35 & 9.41 & 9.09 & 7.66 \\
$\mathrm{C}_{18: 1} \omega 7 c$ 11-methyl & - & 9.48 & - & - & - \\
$\mathrm{C}_{18: 1} \omega 9 c$ & - & - & 3.13 & - & - \\
$\mathrm{C}_{19: 0}$ cyclo $\omega 8 c$ & 12.96 & - & - & 18.2 & 2.27 \\
$\mathrm{C}_{19: 0} 10-\mathrm{methyl}$ & 2.36 & - & - & - & - \\
$\mathrm{C}_{18: 0} 3-\mathrm{OH}$ & 2.72 & - & - & 1.77 & - \\
\hline
\end{tabular}

${ }^{\star}$ Summed features consist of two or more fatty acids that could not be separated by the Microbial Identification System. Summed feature 2 comprised $\mathrm{C}_{12: 0}$ aldehyde, $\mathrm{C}_{14: 0} 3-\mathrm{OH} /$ iso- $\mathrm{C}_{16: 1} \mathrm{I}$ and/or unknown ECL 10.928; summed feature 3 comprised $\mathrm{C}_{16: 1} \omega 7 c$ and/or $\mathrm{C}_{16: 1} \omega 6 c$; summed feature 8 comprised $\mathrm{C}_{18: 1} \omega 7 c$ and/or $\mathrm{C}_{18: 1} \omega 6 c$.

Partial recA (530 bp), atpD (533 bp), gyrB (756 bp) and $g \ln I$ (552 bp) gene sequences were also determined for the new isolate by using the methods and primers reported by Martens et al. (2007). Analysis of these housekeeping gene sequences supported the separate phylogenetic position of the novel strain within the genus Rhizobium. Strain $\mathrm{J} 3-\mathrm{A} 127^{\mathrm{T}}$ shared highest $\mathrm{rec} A$ gene sequence similarity with Rhizobium etli CFN $42^{\mathrm{T}}(89 \%)$ and less than $88 \%$ with the type strains of other species of the genus Rhizobium. The atpD gene sequence of strain $\mathrm{J} 3-\mathrm{A} 127^{\mathrm{T}}$ showed the greatest degree of similarity to that of $R$. oryzae Alt $505^{\mathrm{T}}$ (89\%). In the analysis of partial gyrB gene sequences, strain $\mathrm{J} 3-\mathrm{A} 127^{\mathrm{T}}$ showed similarity levels of less than $85 \%$ with the type strains of recognized species of the genus Rhizobium. The glnII gene sequence of strain $\mathrm{J} 3-\mathrm{A} 127^{\mathrm{T}}$ showed the greatest degree of similarity to that of R. sullae IS123 ${ }^{\mathrm{T}}(89 \%)$. The low levels of similarity between the housekeeping gene sequences of the novel strain and those of recognized species of the genus indicate that this strain may represent a separate species of the genus Rhizobium.

PCR amplifications of the nodD and nifH genes were performed by using primers and conditions as described by Ueda et al. (1995), Laguerre et al. (2001) and Raja et al. (2006). A nodulation test was carried out in a test tube $(18 \times 180 \mathrm{~mm})$ containing quarter-strength nitrogen-free plant nutrient solution (Vincent, 1970). Four legume plant species were selected: soybean (Glycine max), kidney bean (Phaseolus vulgaris), clover (Trifolium repens) and alfalfa
(Medicago sativa). These plants are grown widely in the north of China. After surface-sterilized seeds had been germinated, seedlings were planted aseptically in each tube after being immersed in the culture broth of strain $\mathrm{J} 3-\mathrm{A} 127^{\mathrm{T}}$ with approximately $10^{6}$ cells $\mathrm{ml}^{-1}$ for $1 \mathrm{~h}$. The plants were grown at $25{ }^{\circ} \mathrm{C}$ for 6 weeks in an artificial climate chamber (humidity $55 \%$, light/dark photoperiod of $14 / 10 \mathrm{~h}$ ). Non-inoculated seedlings were used as controls and were cultured under the same conditions. Strain $\mathrm{J} 3-\mathrm{A} 127^{\mathrm{T}}$ did not form nodules on these four legume plants. The nodD and nifH genes were also not detected by PCR in this strain.

For determination of the DNA base composition, total DNA was extracted from each strain according to the method of Marmur (1961). By using the thermal denaturation method (Marmur \& Doty, 1962) and Escherichia coli $\mathrm{K}-12$ as standard, the DNA G + C content of strain $\mathrm{J} 3-\mathrm{A} 127^{\mathrm{T}}$ was $59.5 \mathrm{~mol} \%\left(T_{\mathrm{m}}\right)$. This value was within the range reported for members of the genus Rhizobium (57-66 mol\%; Jordan, 1984).

The results of the present study show that strain J3-A127 is genotypically and phenotypically distinct, and represents a novel species of the genus Rhizobium, for which we propose the name Rhizobium pseudoryzae sp. nov.

\section{Description of Rhizobium pseudoryzae sp. nov.}

Rhizobium pseudoryzae [pseud.o.ry'zae. Gr. adj. pseudes false; L. gen. n. oryzae of rice and also the name of a bacterial specific epithet; N.L. gen. n. pseudoryzae not the true (Rhizobium) oryzae].

Gram-stain-negative, aerobic, non-spore-forming rods $(1.0-1.23 \times 2.3-4.3 \mu \mathrm{m})$. Non-motile. No flagellum is detected. Colonies are circular and pearl white when grown on YMA at $28{ }^{\circ} \mathrm{C}$, which is the optimal growth temperature. The $\mathrm{pH}$ range for growth is 6-11 (optimum $\mathrm{pH} 7-8$ ). The maximum temperature for growth is $40{ }^{\circ} \mathrm{C}$. Positive for catalase, oxidase and urease. Tolerates $\mathrm{NaCl}$ concentrations up to $5 \%(\mathrm{w} / \mathrm{v})($ optimal $1 \%, \mathrm{w} / \mathrm{v})$. Does not reduce nitrate to nitrite. L-Phenylalanine ammonia-lyase is not detected. Does not produce 3-ketolactose from lactose. On GN2 microplates (Biolog), utilizes the following 64 compounds among 95 different carbon sources: dextrin, D-arabitol, cellobiose, D-fructose, L-fucose, D-galactose, gentiobiose, $\alpha$-D-glucose, maltose, D-mannitol, D-mannose, D-psicose, D-sorbitol, sucrose, trehalose, turanose, xylitol, formic acid, DL-lactic acid, succinic acid, bromosuccinic acid, L-alanine, L-alanyl glycine, L-glutamic acid, glycerol, uridine, L-proline, L-asparagine, $\mathrm{N}$-acetyl-D-glucosamine, L-arabinose, myoinositol, $\alpha$-D-lactose, lactulose, methyl $\beta$-D-glucoside, L-rhamnose, pyruvic acid methyl ester, succinic acid monomethyl ester, acetic acid, cis-aconitic acid, D-galactonic acid lactone, D-galacturonic acid, D-gluconic acid, $\alpha$ hydroxybutyric acid, $\beta$-hydroxybutyric acid, $\gamma$-hydroxybutyric acid, $\alpha$-ketobutyric acid, $\alpha$-ketovaleric acid, malonic acid, propionic acid, quinic acid, D-saccharic acid, succinamic acid, D-alanine, glycyl L-aspartic acid, glycyl 


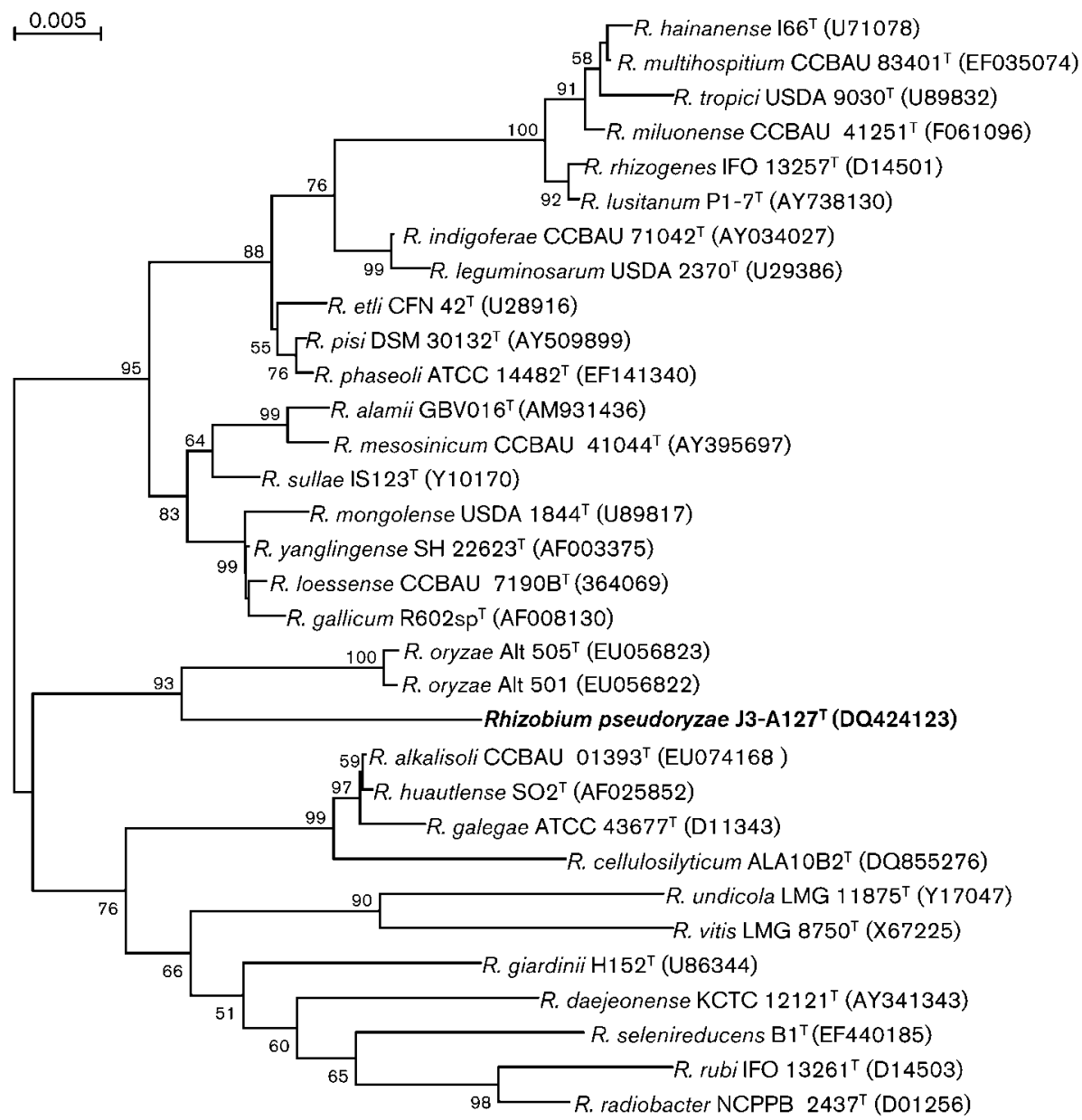

Fig. 1. Phylogenetic tree based on analysis of the nearly complete $16 \mathrm{~S}$ rRNA gene sequences of strain $J 3-A 127^{\top}$ and representatives of the most closely related cultured species of the genus Rhizobium. The branching pattern was generated by the neighbour-joining method. The topology shown was obtained by using 1000 bootstrap replications. GenBank accession numbers are given in parentheses. Bar, 0.005 substitutions per nucleotide position.

L-glutamic acid, L-histidine, L-ornithine, L-pyroglutamic acid, L-serine, L-threonine, urocanic acid, inosine, glucose 1phosphate and glucose 6-phosphate. The main cellular fatty acids are summed feature 8 (comprising $\mathrm{C}_{18: 1} \omega 7 c$ and/or $\mathrm{C}_{18: 1} \omega 6 c, 46.7 \%$ ).

The type strain, J3-A $127^{\mathrm{T}} \quad$ (=ACCC $10380^{\mathrm{T}}=\mathrm{KCTC}$ $23294^{\mathrm{T}}$ ), was isolated from the roots of fresh rice plants (Oryza sativa). The DNA G $+\mathrm{C}$ content of the type strain is $59.5 \mathrm{~mol} \%$.

\section{Acknowledgements}

We would like to express our gratitude to Professor Zhiyuan Tan (South China Agricultural University, Guangzhou, China) for providing the type strain of $R$. oryzae. This work was supported by the National Natural Science Foundation of China (grant no. 30900001), Special Scientific Research Funds for Commonwealth Agricultural Industry (200803029) and the Special Foundation for Central Academy of the Institute of Agricultural Resources and Regional Planning, Chinese Academy of Agricultural Sciences (2009-10).

\section{References}

Berge, O., Lodhi, A., Brandelet, G., Santaella, C., Roncato, M. A., Christen, R., Heulin, T. \& Achouak, W. (2009). Rhizobium alamii sp. nov., an exopolysaccharide-producing species isolated from legume and non-legume rhizospheres. Int J Syst Evol Microbiol 59, 367-372.

Chun, J., Lee, J.-H., Jung, Y., Kim, M., Kim, S., Kim, B. K. \& Lim, Y. W. (2007). EzTaxon: a web-based tool for the identification of prokaryotes based on $16 \mathrm{~S}$ ribosomal RNA gene sequences. Int J Syst Evol Microbiol 57, 2259-2261.

Dong, X. Z. \& Cai, M. Y. (2001). Determinative Manual for Routine Bacteriology. Beijing: Science Press (in Chinese).

Euzéby, J. P. (1997). List of Bacterial Names with Standing in Nomenclature: a folder available on the Internet. Int J Syst Bacteriol 47, 590-592.

Frank, B. (1889). Über die Pilzsymbiose der Leguminosen. Ber Dtsch Bot Ges 7, 332-346 (in German).

Gao, J. L., Sun, J. G., Li, Y., Wang, E. T. \& Chen, W. X. (1994). Numerical taxonomy and DNA relatedness of tropical rhizobia isolated from Hainan Province, China. Int J Syst Bacteriol 44, 151-158. 
García-Fraile, P., Rivas, R., Willems, A., Peix, A., Martens, M., Martínez-Molina, E., Mateos, P. F. \& Velázquez, E. (2007). Rhizobium cellulosilyticum sp. nov., isolated from sawdust of Populus alba. Int J Syst Evol Microbiol 57, 844-848.

Hunter, W. J., Kuykendall, L. D. \& Manter, D. K. (2007). Rhizobium selenireducens sp. nov.: a selenite-reducing $\alpha$-Proteobacteria isolated from a bioreactor. Curr Microbiol 55, 455-460.

Jordan, D. C. (1984). Genus I. Rhizobium Frank 1889, $338^{\mathrm{AL}}$. In Bergey's Manual of Systematic Bacteriology, vol. 1, pp. 235-242. Edited by N. R. Krieg \& J. G. Holt. Baltimore: Williams \& Wilkins.

Laguerre, G., Nour, S. M., Macheret, V., Sanjuan, J., Drouin, P. \& Amarger, N. (2001). Classification of rhizobia based on nodC and nifH gene analysis reveals a close phylogenetic relationship among Phaseolus vulgaris symbionts. Microbiology 147, 981-993.

Lin, D. X., Chen, W. F., Wang, F. Q., Hu, D., Wang, E. T., Sui, X. H. \& Chen, W. X. (2009). Rhizobium mesosinicum sp. nov., isolated from root nodules of three different legumes. Int J Syst Evol Microbiol 59, 1919-1923.

Marmur, J. (1961). A procedure for the isolation of deoxyribonucleic acid from micro-organisms. J Mol Biol 3, 208-218.

Marmur, J. \& Doty, P. (1962). Determination of the base composition of deoxyribonucleic acid from its thermal denaturation temperature. J Mol Biol 5, 109-118.

Martens, M., Delaere, M., Coopman, R., De Vos, P., Gillis, M. \& Willems, A. (2007). Multilocus sequence analysis of Ensifer and related taxa. Int J Syst Evol Microbiol 57, 489-503.

Peng, G. X., Yuan, Q. H., Li, H. X., Zhang, W. \& Tan, Z. Y. (2008). Rhizobium oryzae sp. nov., isolated from the wild rice Oryza alta. Int $J$ Syst Evol Microbiol 58, 2158-2163.

Quan, Z. X., Bae, H. S., Baek, J. H., Chen, W. F., Im, W. T. \& Lee, S. T. (2005). Rhizobium daejeonense sp. nov. isolated from a cyanide treatment bioreactor. Int J Syst Evol Microbiol 55, 2543-2549.

Raja, P., Uma, S. \& Sundaram, S. (2006). Non-nodulating pinkpigmented facultative Methylobacterium sp. with a functional nifH gene. World J Microbiol Biotechnol 22, 1381-1384.
Sasser, M. (1990). Identification of bacteria by gas chromatography of cellular fatty acids, MIDI Technical Note 101. Newark, DE: MIDI Inc.

Squartini, A., Struffi, P., Döring, H., Selenska-Pobell, S., Tola, E., Giacomini, A., Vendramin, E., Velázquez, E., Mateos, P. F. \& other authors (2002). Rhizobium sullae sp. nov. (formerly 'Rhizobium hedysari), the root-nodule microsymbiont of Hedysarum coronarium L. Int J Syst Evol Microbiol 52, 1267-1276.

Tamura, K., Dudley, J., Nei, M. \& Kumar, S. (2007). MEGA4: Molecular evolutionary genetics analysis (MEGA) software version 4.0. Mol Biol Evol 24, 1596-1599.

Tan, Z. Y., Kan, F. L., Peng, G. X., Wang, E. T., Reinhold-Hurek, B. \& Chen, W. X. (2001). Rhizobium yanglingense sp. nov., isolated from arid and semi-arid regions in China. Int J Syst Evol Microbiol 51, 909914.

Thompson, J. D., Gibson, T. J., Plewniak, F., Jeanmougin, F. \& Higgins, D. G. (1997). The CLUSTAL_X windows interface: flexible strategies for multiple sequence alignment aided by quality analysis tools. Nucleic Acids Res 25, 4876-4882.

Tighe, S. W., de Lajudie, P., Dipietro, K., Lindström, K., Nick, G. \& Jarvis, B. D. (2000). Analysis of cellular fatty acids and phenotypic relationships of Agrobacterium, Bradyrhizobium, Mesorhizobium, Rhizobium and Sinorhizobium species using the Sherlock Microbial Identification System. Int J Syst Evol Microbiol 50, 787-801.

Ueda, T., Suga, Y., Yahiro, N. \& Matsuguchi, T. (1995). Remarkable $\mathrm{N}_{2^{-}}$ fixing bacterial diversity detected in rice roots by molecular evolutionary analysis of nifH gene sequences. J Bacteriol 177, 1414-1417.

Vincent, J. M. (1970). The cultivation, isolation and maintenance of rhizobia. In A Manual for the Practical Study of the Root-Nodule Bacteria, pp. 1-13. Edited by J. M. Vincent. Oxford: Blackwell Scientific.

Zhang, X. X., Sun, L., Qiu, F. B., McLean, R. J. C., Jiang, R. B. \& Song, W. (2008). Rheinheimera tangshanensis sp. nov., a rice root-associated bacterium. Int J Syst Evol Microbiol 58, 2420-2424. 